MA MAJOR RESEARCH PAPER

ISSUES OF COMMUNICATION IN THE WORK OF JEAN-JACQUES ROUSSEAU

MARK SEDORE

[for] Prof. Bruce Elder

The Major Research Paper is submitted

in partial fulfillment of the requirements for the degree of

Master of Arts

Joint Graduate Program in Communication \& Culture

Ryerson University - York University

Toronto, Ontario, Canada

September 13,2011 
The 1700 s were an exciting and transformative time for mass communications in the Western world. Newspapers were finally coming into their own and novels were rising as a distinct genre, a movement led on the continent Goethe and Voltaire, and in England by Richardson, Defoe and Fielding. Political commentary disseminated through bulletins or one-sheet news announcements was vibrant and the growing use of moveable-type printing presses enabled cheap, quick and wide distribution of printed information. While much modern scholarly work has related the introduction of these innovations to political and social life, fewer analysts take a close look at what was being written about communications in general, by the most notable thinkers, during this period.

Jean-Jacques Rousseau wrote extensively about both the political-social environment of his time, and about the potential for new ways of living. His considerations of communication thought are scattered throughout his works, and do not form a unified whole; I argue that threads of coherence run through his writing and that his thinking was deeply influenced by the increase in printing and mass communication, developments that would have been evident during his lifetime.

After a brief introduction to Rousseau's life and his personal concerns with communication, this essay will outline five touch points regarding communication in his body of work: his thoughts on conversation both personal and formal; his thoughts on the development of speech in children; his theories on the origins of language for humankind; his philosophies on books and the book industry, and; his innovative use of other communications vehicles and relationship to mixed media in $18^{\text {th }}$ century Europe - to engage in discourse with detractors, perceived enemies and a supportive public. 
Rousseau began his professional career as an apprentice engraver - indelibly scrawling onto pieces of metal, compelling his words to last forever. He ended his life as a renowned and notorious writer (thereby making words last forever in a different respect) and, despite having renounced both writing and publishing about two decades prior to his death, he nevertheless remained tremendously prolific, writing his Dialogues, Confessions and the Reveries of a Solitary Walker, works which he only intended to be released posthumously. Between his time as an engraver and that of a reluctant philosophe, Rousseau made most of his day-to-day income by transcribing music. Thus, his entire professional life was devoted to the art of communication. It is perhaps unsurprising that the complexities and difficulties of human communication never seemed to be far from his mind.

Taking a broad view of his work, it is clear that Rousseau saw his life as being plagued by a failure to communicate properly. He was an awkward and easily-embarrassed public speaker, a man who felt that not even his lovers and closest friends could understand him, while some of his most heartfelt and thoughtful writings were widely interpreted to mean the opposite of what he intended and banned in countries across Europe during his lifetime. Rousseau's personal problems with not being understood were reflected in many of his writings which deal, sometimes directly and sometimes incidentally, with a myriad of communication problems. In fact, Rousseau's first published work (and that which propelled him to celebrity as a writer of influence - his Discourse on the Sciences and the Arts) begins with this quote from Ovid:

In this place I am the barbarian, because men do not understand me. 
Through his later autobiographical works, Rousseau reveals his feelings about constantly being misunderstood both in his public writing and by his personal acquaintances. His lengthy Confessions abound with tales and allusions to unjustified persecution, revealing a height of suffering - and precaution - that comes across as nothing less than paranoia. Rousseau's feelings of paranoia grow to such proportions in the final decades of his life that he believes he has enemies around every corner and that the leaders of most of the countries of Europe are set on his downfall. Although scholars have since shown that some of this paranoia was justified Rousseau was in fact the subject of a number of real plots against him - Jean-Jacques was perhaps better understood and sympathized with by his reading public than he could appreciate. Indeed, he was interred as a national hero in the Panthéon in Paris in 1794, 16 years after his death.

\section{Conversation and Oral Discourse}

Rousseau was frequently uncomfortable when he had to speak. He had as little control over his conversation as he did over his emotions; he could never find the right phrases to use, and the right phrases could neverfind him. In his writing, Rouszeau comes across as sympathetic in his tales of awkwardness, yet, what bothers him most is "not his inability to communicate his thoughts or defend his ideas but the difficult time he has proving his mettle. In an eighteenthcentury 'circle' one defended one's ideas only in order to defend one's 'quality' against adverse judgment" (Starobinski 123). According to his own accounts in his Confessions, Rousseau stammered and couldn't hold his own in a polite debate or dinner conversation. This shamed 
him since, "the fact that he says nothing means that he is nothing. He is nothing if he does not speak, and when he does speak it is in order to say nothing or, in other words, to annihilate himself, as though he opened his mouth only to punish himself for speaking" (ibid).

Although as an adult he would feel persecuted primarily by the failure of his reading public to understand him, during his youth and young adulthood Rousseau felt oppressed by this inability to communicate orally. In a time when wit, intelligent conversation and smart discourse were the marks of a cultured man, Rousseau was by his own admission consistently unable to call forth in speech the insight and profoundness that was later evident in his writing. He felt that this prevented him from attaining those highest ranks of society to which he had always aspired, and he was envious of those - people he usually considered his inferiors - who could orally spar with spontaneous and easy wit. This is most obvious in the following passage from his Confessions:

Since I am so little in possession of my wits when I am on my own, it is easy enough to judge what I must be like in conversation, where if you are to say something suitable you must be able to call to mind, instantaneously and simultaneously, a thousand things. The very thought of all those proprieties, of which I am certain to forget at least one or the other, is enough to intimidate me. I cannot conceive how anyone dares to speak at all in company; for with every word you utter you must consider all the people who are present; you must be acquainted with all their characters, you must know their lifehistory, so as to be sure not to say anything that might offend anyone. (112) 
If speaking in mixed company is a problem for Rousseau, so too is speaking one-on-one, where there was an obligation on the participants to continue talking the whole time. As he writes in his Confessions, "if someone speaks, you must reply; if they say nothing, it is up to you to revive the conversation" (113). This "intolerable burden" so much frightens Rousseau that he can imagine nothing "more terrible than that of having to go on conversing, on the spur of the moment and forever" (ibid). Rousseau is so frightened of speaking that he is convinced that the moment he is obliged to talk, he will infallibly utter some stupidity. What is even more fatalaccording to him - is that, instead of staying silent when he has nothing to say, that is "precisely the moment when, in order to discharge my debt as soon as possible, I am seized with the urge to speak. I cannot wait, but promptly begin stammering out some inanity, which, if I am very lucky, means nothing at all. In trying to conquer or disguise my ineptitude, I rarely fail to reveal it" (ibid).

Despite trying to avoid all such situations, eventually Rousseau "would be required to speak, and to speak on the spur of the moment, to summon up on the spot ideas, turns of phrase, and words, always to keep my wits about me, always to be cool and collected, never to suffer a moment's confusion. Whereas what could I hope for from myself, I who felt so keenly my inability to speak impromptu?" (Confessions 612). To get past this inability to speak Rousseau would occasionally, when invited to lecture in public, compose a vast speech that would allow for no response from his interlocutor or audience, and then commit it to memory. Unfortunately, as happened on at least one occasion, the words failed him when it was time to recite them, and he would be forced to send his speech by post, rather than in person.

Once, after failing to come up with anything to say to a young girl in his presence, Rousseau instead asks her for a kiss, contrary to advice he gives to his readers in Emile on 
forcing children to show affection when it's not voluntary. Upon reflection, he subsequently curses his own "unbelievable stupidity" (suggesting that perhaps not all in Emile is meant as impractical thought experiments and philosophical lessons and that some, at least, of Rousseau's instruction was sincere) "which has so often made [him] appear despicable and guilty when [he] was merely silly and awkward. A stupidity, moreover, that has often been regarded as a poor excuse, coming from a man who is known not to be entirely lacking in wit" (Confessions 524).

Even when in the presence of his two closest friends - people he lived with for years Rousseau feared pauses in conversation so much that he took to carrying a cup-and-ball in his pocket, with which he would occupy himself rather than feel the need to speak when he had nothing to say. He couldn't stand the habit that many of his contemporaries had of exhausting their brains only to fill up conversation with an unstoppable flow of empty words, and he felt that if only all of society would adopt a similar program of self-restraint in conversation (the "morality of the cup-and-ball"), then "people would be less mischievous, their dealings with one another would be more straightforward and ... more pleasant" (Confessions 198).

Rousseau's inability to communicate in polite society eventually resulted in his fleeing polite society. Jean Starobinski argues that Rousseau repeatedly fled (as he did a number of times in his life) only to write, but that he wrote only in order to be accepted and praised. If he had been accepted by society in the first place, he would have felt no impetus to write; rather, "Jean-Jacques decides to write and to hide. But he writes only in anticipation of the miraculous moment when words will cease to be necessary, and he hides only in the hope that there will come a time when he will have only to show himself [and not speak] in order to be recognized" (137). 
Rousseau's inability to communicate orally becomes such a problem that even while living in seclusion, he would fear visitors and would take to saying nothing at all. This, however, only results in him being accused of being "a misanthropist, a wild beast, a bear ... it would have been much better for me if I had been a total imbecile; instead of which, my lack of social accomplishment has tumed such accomplishments as I do possess into the instruments of my ruin" (Confessions 524). At the end of his life he regrets how it all tumed out, his relationships with his friends and others, and how much better his situation would have been, if only he could have been able to speak eloquently, as if his pen were in his mouth (Confessions 612). As will be shown below, Rousseau's personal problems with communication, and specifically his fear of being misunderstood, would lead him to ponder at length both the problem of the origin of language and modern communication between people in a number of his works.

Rousseau knew French - his native language - very well. He knew the origins of words, the different inflections, subtleties, tenses and flavours of them. That said, he did have a problem with the paucity of words in French, which forced him constantly to use the same word for different ideas. This was frustrating at times, for "the method of defining all the terms and constantly substituting the definition in the place of the defined is fine but impracticable ... definitions could be good if words were not used to makt them" (Emile 108, footnote). Rousseau usually relies, therefore, less on re-defining his terms as he goes along than on requiring his readers to understand his definition from the context. He realizes that sometimes this results in contradictions in his expressions, but he holds that he never contradicts his meanings in in his work (at least within the body of a single work). If Rousseau was himself so 
prone to redefining terms and asking his readers to know what he means rather than what he says, was it not unfair of him later to be offended when he was misunderstood?

Rousseau was also among other things a musician. He wrote operas and spent most of his professional life transcribing music; he felt strongly that musical education in children was just as important as literacy with words. However, while he believes that people around the world can take pleasure in hearing beautiful sounds, "if this pleasure is not enlivened by melodious inflections that are familiar to them, it will not be at all delightful, it will not become voluptuous. The songs most beautiful to us will only moderately move those to whom they are quite unfamiliar. It is a language for which one needs a dictionary" (Essay on the Origin of Languages 120). Thomas Kavanagh holds that it's notable that Rousseau - who was such a strong advocate for direct and unmediated sensations of nature - would claim in his later career that humankind requires a dictionary to understand something as fundamentally interpretable as music. And, if this is indeed what Rousseau means, then this idea of the dictionary implies that before man understands anything even so basic as music, he "must interiorize a code, learn the equivalences dictated by a system of arbitrary connections between word and meaning ... and a dictionary we must acquire is, by definition, a dictionary we did not originally possess. To learn such a code, therefore, is to step beyond nature into culture" (51). This would require the transformation "of our otherwise direct experience of sound and music. Such a code may well give us something more; but it does so at a price - that of a learned response that mediates between reality and our unmediated experience of it" (ibid).

Why would Rousseau, someone so in touch with the primal experiences of nature, suggest that people need a context in order to understand music? Kavanagh suggests that "our present form of syllabic writing, coming after hieroglyphic and ideogrammatic writing, 
represents the final stage of this progression" towards a "conventional' language that forces the communicators to rely on previously-decided upon rules (55). "Syllabic writing is the coded, visual representation of a spoken language that is itself already and differently coded. Syllabic writing is a second encoding of what is already encoded" (ibid). If this is the case, then perhaps music is also a secondary coding of expressions we feel within ourselves and, for Rousseau, coded representational systems should be seen primarily as tools of deception - which is why he goes to such lengths throughout his career to investigate the origin of language.

Rousseau frequently experienced problems with being understood and with being able to converse eloquently, using words he was intimately familiar with in his own native language. So if something as familiar and natural to him as the use of the French language can result in his being misunderstood, and if something as emotionally-charged and pure as music can lie to us, then there seems little reason to hope for truth in communication among people. Perhaps the only way we can arrive at any sort of truth in communication is if we can understand why and how oral/aural communication originated. But before we deal with Rousseau's approach to the origin of languages, we might benefit from an analysis of how he feels children should be educated in language and music.

\section{Speech and the Education of Children}

Despite his own inadequacies with the medium, Rousseau was aware that speech had great capacity for influencing people, and particularly children. He knew, for example, that one cannot control every word ever spoken around a child while he grows and that this will pose problems for any educator. In order to rectify this in Emile, Rousseau's lengthy tract on 
education, he suggests raising the child away from society for the first years of his life, allowing him only to have contact with his tutor (38). This will enable the educator to control the words and phrases the child is exposed to. Rousseau believes that a child "should hear only words he can understand and say only those he can articulate ... he will know how to talk well on his own to the extent that he comes to sense the utility of it" (73).

Among the many pieces of child-rearing advice Rousseau provides, he holds it necessary to restrict a child's vocabulary as much as possible early in his life, for "it is a very great disadvantage for him to have more words than ideas, for him to know how to say more things than he can think" (Emile 74). Restricting their vocabulary would at the very least allow children to have clear thoughts and minds. Rousseau believes that "the reasons why peasants generally have clearer minds than city people is that their lexicon is less extensive. They have few ideas, but they are very good at the comparison of ideas" (ibid). It is important that one sees the meaning behind words even in speech; and especially children. A child doesn't know many words and, when he speaks, we are required to see the motives behind his speech, rather than paying attention to the words he pronounces (Emile 172). We should not strive to make the world clear to children through speech but, rather, to give them the curiosity to want to understand the world, and the capacity to do so. It is less important that children think we know everything and can answer all their questions than it is that they have confidence in their own ability to seek answers and find them (Emile 179). One wonders if Rousseau was frustrated by being unable to communicate his own thoughts adequately in speech and that sometimes he wished people would be able to perceive his motives behind speaking, rather than the words he was using. Perhaps he thought the least society could do was treat children with more faimess. 
In Emile, Rousseau further holds that the communication and slow adoption of language by children is a common trait in each of them, and understood by those who work with children constantly, such as nurses (65). Even though very young children all use the same method of communication (i.e. crying) there are subtleties in the different tones and meanings behind a child's cries, meanings which can, by an astute observer, be deciphered and understood. However, Rousseau warns that the cries of children should be analyzed with care and not always listened to indiscriminately, lest the child grow to rely on those around him, or become a tyrant, dictating orders to everyone when he is just as able to perform the same tasks himself; "it does not require long experience to sense how pleasant it is to act with the hands of others and to need only to stir one's tongue to make the universe move" (Emile 68). Rousseau warns educators and parents from submitting to the whims of children, and advises that "one must study their language and their signs with care in order that, at an age at which they do not know how to dissimulate, one can distinguish in their desires what comes immediately from nature and what comes from opinion" (Emile 68). Despite the care Rousseau insists adults take with children, he ultimately argues for giving them more true freedom and less strict instruction. The capacity to lie - a common theme for Rousseau - is of utmost concern. If something as pure as music is capable of lying, then children learning to speak certainly are as well. We must be careful to teach them not to lie even before they are able to understand why they shouldn't. For Rousseau, truth in language should always be striven for, even though it may be rarely achieved.

Rousseau would only allow children to read once it became useful to them, sometime around the age of twelve or so. Prior to reading being useful for a child, it should certainly not be employed as a way to keep them occupied by, for example, giving them novels. Children have so many more actually and practically productive things with which to occupy themselves 
than reading books (Emile 116). Give the child "no book other than the world, no instruction other than the facts. The child who reads does not think, he only reads; he is not informing himself, he learns words" (Emile 168).

Rousseau believes that children should only be exposed to books and religion once they are able to analyze them; the same with newspapers and similar media (Emile 344). Of course, Rousseau is occasionally a media sceptic and believes that once a person is able to analyze newspapers, he will read one once and never return to them. Regarding the cultural transmission of knowledge (and anticipating the work of Eric Havelock by about 150 years) Rousseau writes,

I hate books. They only teach one to talk about what one does not know. It is said that Hermes engraved the elements of the sciences on columns in order to shelter his discoveries from a flood. If he had left a good imprint of them in man's head, they would have been preserved by tradition. Well-prepared minds are the surest monuments on which to engrave human knowledge. (Emile 184)

Today we are suffering from information overload no less dramatic than the sort experienced by Rousseau and his contemporaries - perhaps even more so. The impact of printing presses in the centuries leading up to the 1700 s might be compared to the impact of the Internet. Now almost everyone in the Western World has affordable private - and in many cases free public - access to the World Wide Web. This means that the availability of information is (without hyperbole) exponentially greater than that to which Rousseau had access. One might claim that, therefore, we have a more difficult time exposing ourselves to meaningful data. Yet, since today all our information is digital, we also have the advantage of digital assistance and 
assistants, like search engines, online library catalogues, and even such taken-for-granted devices as in-document keyword searches.

However, the ubiquity of information for us is only one side of the coin. The other (which Rousseau might see as a disadvantage, rather than an advantage) is that so many of us have cheap or free access in making our opinions publicly known. In Rousseau's time, despite the vast increase in the number of printing presses, publications were still restricted to a small minority. Today, one can find more information in an average weekday edition of the New York Times than the average person living in England in the 1700s would have had access to in a lifetime (Wurman 38).

So for the past few hundred years it seems that it has been impossible to learn much from books (or blogs?) alone - almost contrarily because there are so many of them. For Rousseau, the obstacle was that countless languages must be acquired, and countless libraries must be gone through to find the best books that cover exactly what one is searching for. Today, it's that tens of thousands of web results may have to be filtered before we find precisely what we're looking for. More than this though, for Rousseau it is that we give preference to the authority of books on shelves over the book of life (or today to the World Wide Web than to the actual world).

Rousseau also holds that the reliance on books kills science because we come to trust knowledge given to us and use its authority rather than that which we can discover ourselves. Believing that we know what we have read, "we believe that we can dispense with learning it. Too much reading only serves to produce presumptuous ignoramuses. Among all literary ages there has been none in which men read so much as in this one, and none in which men are less knowledgeable ... so great a number of books makes us neglect the book of the world" (Emile 450-51). 
For Rousseau, the instruction of children and their ability to make judgments is intimately related to a choice of religion. He finds it interesting, for example, how all three major religions of his time (Judaism, Christianity and Islam) all rely on knowledge from books, knowledge that was originally written in languages that - excepting a small number of scholars - its followers no longer understand. Who can assure adherents that the books are faithfully translated, or even that it's possible for them to be? For, "if God has gone so far as to speak to men, why must $\mathrm{He}$ need an interpreter?" (Emile 303). Rousseau's concerns with - and intended defence of religion in Emile later cause the book to be banned in France and Geneva. In trying to defend religious belief, Rousseau was seen as attacking it - one of the most perilous misunderstandings of his career. This will be looked at in greater detail below.

Although he never raised children of his own (though he did have five children by his companion Thérèse Levasseur, they gave all their children to a foundling home), Rousseau undertook to write this book on education. While it is presented as an instruction manual on how to raise a young boy, Allan Bloom - translator of a modern edition of the work - suggests that Rousseau's Emile is not a manual “any more than Plato's Republic is advice to rulers. Each adopts a convention - the founding of a city or the rearing of a boy - in order to survey the entire human condition. They are books for philosopher and are meant to influence practice only in the sense that those who read them well cannot help but change their general perspectives" (28). So Rousseau's largest philosophical work is itself a coded treatise on the human condition. Perhaps, realizing that all language can be misunderstood, Rousseau chose instead to be misunderstood on his own terms.

For Rousseau, the meaning of language is just as important as its use, be it in a cultural, educational or religious context. As with music's ability to lie, and the ability of children to fib 
from the moment they learn language, Rousseau is frequently concerned with humankind's not just ability, but almost eagemess or even need to dissemble. This unreliability of language to proclaim the truth led him to a concern with the origins of language, in a search for how to improve and perfect it.

\section{On the Origin of Languages}

Rousseau holds that it is primarily communication and language that separates us from primitive man; that primitive man excels physically in every way from modern Europeans, and that this is directly a result of a refinement in language of the latter and the correspondingly more simple, less abstract thought in the former (Discourse on the Origin of Inequality 87). He thinks that many of the explorers who (during his time) describe the greater apes have mislabelled these and that these creatures should more properly be described as savage men who have not yet attained language; so much does language separate beasts from men (DI 97). He writes, regarding the apes and their lack of technology and society, that

it is easy to conjecture that it is on account of their stupidity and also because they did not speak - feeble reasons for those who know that although the organ of speech is natural to man, nevertheless speech itself is not natural to him, and who knows to what point his perfectibility can have elevated civil man above his original state. (DI 97)

If improved language is linked to physical deterioration, then any striving towards a perfection of language or communication would suggest an even greater decline in the physical faculties of 
modern man. Rousseau agrees with this deduction when he earlier dismisses the possibility of any advancement towards perfection in language, concemed that even if we were to achieve it, that it would come at a tremendous price (DI 94). But is there some way we can have both - a perfect communication system and an idyllic, honest lifestyle, as enjoyed by pre-literate man? Rousseau thinks that perhaps some clues to language's perfectibility may be found in its origins.

According to Jean Starobinski, Rousseau's concerns with the origins of language arise from his being personally so prone to being misunderstood and the victim of miscommunication. Between our thoughts and our meanings there can be a huge gap; it is not for humans to communicate immediately and purely as it would be for gods, or those with powers like to telepathy; immediate communication is impossible, hence we must resort to gestures and perceptible signs; "men need a conventional language, because thought cannot be communicated immediately" (140). Since we must necessarily resort to signs, be these communicated through gestures or words or music, we must necessarily rely on intermediate symbols to denote what we mean. For Starobinski, "everything that [Rousseau] writes on the subject of language reveals a very clear understanding of why conventional signs are necessary, coupled with regret that more direct modes of communication are not possible" (143). But what is it that Rousseau says?

He devotes considerable thought in a number of his works to problem of the origin of language. His longest contemplation on the topic can be found in his Essay on the Origin of Languages, although this work was unfinished and unpublished in his lifetime. His more refined and widely-read views can be found in his second discourse, the Discourse on the Origin of Inequality (1754), excerpts from which he refers to later in Emile and his Confessions. In this work, Rousseau contemplates at length his theory of the origin of language and the obstacles that should have prevented language from ever being developed. 
One might argue that perhaps Rousseau intended his theories on the origins of language (outlined below) to be extended parables that his readers can use as philosophical platforms, from which to ruminate on more broad issues like the origins of human civilization, society or cooperation. Allan Bloom, as mentioned above, points out that Rousseau intended his Emile to be just such a document (28). In relation to the origins of language, a similar conjecture might have some merit (because why would Rousseau otherwise have spent so much time on a matter of seemingly purely historical interest?), but there exists strong evidence to support that Rousseau was likely being sincere when explicating his theories on the origins of language. First, he does not outright disclaim the literal intent of his argument in the way that he does with Emile (see above). Second, his occasional discussions on the origins of language are not couched in the guise of some other objective. Emile is written $a s$ advice to teachers of young people; the origins of language are written as theories derived from first principles - it seems difficult to derive a deeper, more fundamental meaning than this. Third, Rousseau's contemporary philosophers spent much time debating the origins of language, including a thinker no minor than John Locke, whom Rousseau was a reader of, if not an outright admirer (Emile 89-103). Since Rousseau was formulating his theories on language in his Discourse on the Origins of Inequality when he was still new in his career it seems likely that he was being sincere; in Emile, his reputation had already been established, and he could afford to speak more vaguely about overarching issues than he could in the former work. This would also explain why he chose to deliver his theories in philosophical prose rather than in a more poetical form (as he did in The New Heloise, a novel, and arguably also in Emile); explicitness would have been key during this time in his career. Lastly, Rousseau was constantly trying to make a name for himself and display his cleverness to the public, so it seems unlikely that a younger (and 
occasionally desperate) writer would hide his true meanings in something tangential to what he was getting at, particularly in such a cutting-edge area of study like the origins of language, prior to the modern development of philology or linguistics. Thus it seems clear that Rousseau was sincerely trying to put forth new ideas in an area that his most admired contemporaries were themselves trying to grapple with.

When explicating his theories he first outlines a problem not original to him; that since language had not been necessary to human survival prior to its invention, nothing should have come along that would have made its invention inevitable and its use among people necessary. If humankind had been well-enough equipped to live without language in the first place, why did we ever invent it? Furthermore, before language is created it is the child who has greater need of it, to make his needs known, than the mother does to make her needs known to the child. Thus the onus of invention would be on children and, since children are not raised in a forum of their peers replete with discussion and consensus, the number of possible proto-languages being invented would be "multiplied as many times as there are individuals to speak them" (DI 49). The assumption that a mother would teach her child certain words with which to communicate may be a good example of how already-formed languages are taught, but it does not illustrate in the first place how languages are formed (ibid).

Eventually putting these many objections aside, Rousseau grants that perhaps there was some impossible-to-imagine situation in which language was necessary to those non-linguistic primitives living in a state of nature. How, then, might language have been formed intentionally among people who lack reason? According to Rousseau, if men required speech in order to learn to think, they had a still greater need for knowing how to think in order to discover the art of speaking. And even if it were understood that vocal sounds could represent conventional 
expressions of our ideas, it would still remain for us to determine words for ideas that, not having a sensible object, could not be indicated either by gesture or by voice (DI 51). These difficulties suggest that we might not ever understand how language was originally formed, which is more the pity since, were we able to understand it, we might be able to improve upon modern languages and bring them to some kind of perfection, a difficulty that the academies would be unable to surmount, "even if they were able to occupy themselves with that thorny problem for whole centuries without interruption" (ibid).

These are some of the problems to Rousseau's theories around the origins of language that he must deal with. Returning to the objections in order to solve the problem, he suggests that language evolved out of a combination of a primitive cry for help and the natural inclination to use gestures to indicate objects. Since gestures are primarily useful for indicating those things which are immediately present, and are affected by darkness or the interposition of other objects in the way, he suggests that vocal inflections came to signify objects of prior determination (DI 51). The most personal aspect of the problem for Rousseau is that, before men had invented language, they "found their safety in the ease with which they saw through each other, and that advantage, which we no longer value, spared them many vices" (DI 50). Before men had language, lying had been impossible. One can't convincingly feign being in love, or being hurt or hungry without language. The signs we used between each other to convey these feelings prior to speech - were not subject to misinterpretation.

The theory of language gradually becoming necessary relies on the common consent of people as to which words refer to which objects, and this consent could only have arisen if people were already living in communities and not in a nomadic state of nature. Rousseau affirms that achieving common consent would have been difficult, since unanimous agreement 
needed to be conveyed and, thus, "speech appears to have been necessary in order to establish the use of speech" (DI 50). Later in the same discourse, Rousseau suggests that it is easy to see that language, for the longest part of humanity's existence, was not "much more refined than that of crows or monkeys ... inarticulate cries, many gestures, and some imitative noises must for a long time have made up the universal language" (DI 62). He speculates that the first languages would have used single words to take the place of entire sentences, that the present tense would have been the only one available, and that the development of adjectives, in particular, would have been no mean feat of genius, since all adjectives are abstractions and not particularly natural (DI 50). He also suggests that the grouping of objects into like units would have been tremendously difficult; for there would not initially have been a single word to mean "tree" but rather one word for this specific tree, and another for that tree. Only later would men be able to decide that a single word could be employed for all trees, and subsequently for oak trees, birch trees, etc. (ibid). If the first inventors of languages "could give names only to ideas they already had, it follows that the first substantives could not have been anything but proper nouns" (DI 51).

He suggests that while language was obviously - at some point - invented and spread around the world, the time involved for this transmission must have been immense, for even assuming the representation of the most basic nouns into spoken words, "reflect upon how much time and knowledge were needed to discover numbers, abstract words, aorists, and all the tenses of verbs, particles, syntax, the connecting of sentences, reasoning and the forming of all the logic of discourse" (DI 51). He poses to his readers the question: "which was the more necessary: an already formed society for the invention of languages, or an already invented language for the establishment of society?" (ibid). 
Rousseau suggests that, since a close-living community does seem to be required for the development of language, it is quite possible that the first languages were developed by people forced to live together on islands, rather than as nomads. Men may have been driven to islands through upheavals or floods and thus developed language for clearly, among men thus forced to live together, a common idiom must have been formed sooner than among those who wandered freely about the forests of the mainland. Thus it is quite possible that after their first attempts at navigation, the islanders brought the use of speech to us; and it is at least quite probable that society and languages came into being on islands and were perfected there before they were known on the mainland (DI 63).

Now, empowered by language and able to communicate with each other, people stopped wandering and began to settle down, assuming a more fixed situation and coming together and uniting into bands, each eventually forming nations united by similar mores and characteristic features. Thus, islands forced society on people, society forced language on (island) people, and once this began to spread, language in turn forced society back on (mainland) people. Those people who were the most eloquent, the most talented (in physical feats and music as much as in language) came to be the most esteemed, and their talents were envied and imitated (DI 64). Thus it became a matter of pride to become adroit at language, not just to cooperate with your fellow men, but to win over the love of members of the opposite sex.

These are possibly the precise failings that Rousseau suffers from; he can neither make himself known to his friends, nor win public acclaim, nor have the meaningful relationships with women that he aims for. For one so adept at the written epigram, he feels the weight of his oral impotence when communicating in person; thus the importance to him of discovering the origin 
of languages - and thus lies, and codes. The clearest result of this proliferating reliance on these forms of communication is the creation of:

an age Rousseau would define as coterminous with civilized society. As signs, the cry and swoon are marked by direct, unmediated links to the hunger and longing they signify. They are ... indexical signs. There is an unbreakable, existential relation between the form of the enunciation and the meaning they convey. By their very nature they are poorly suited to misrepresentation. At the other end of the spectrum, syllabic writing, the medium privileged by all advanced societies, lacks any necessary connection between the form of its expression and the represented meaning. (Kavanagh 55).

Writing is thus the perfect tool for creating a society of liars.

Rousseau was aware that even when literate people speak face-to-face with one another, their conscious or unconscious accommodation of the secretiveness of writing encourages their erasing all visible signs of the deeper significances that might otherwise (and certainly in a preliterate society) accompany what they say (Kavanagh 56). This is one of the reasons why the origin of language is so important to Rousseau. For him, "sometimes words can do nothing, sometimes they can do everything: they fail to dispel misleading 'appearances,' yet they inspire 'prejudices' capable of vanquishing truth. No words can convey the inner conviction of innocence, while fiction proves strangely believable" (Starobinski 122). So, for a man who cannot communicate orally, what recourse is left to him? He clearly must write; either philosophical and political treatises, or fiction, or autobiography; the genre matters only insofar as it gets his meaning across. He wants to be known, but he fears being misunderstood. For 
Rousseau, experimentation with different media is an extension of his exploration into the origin of language. Since language and music are merely two different aspects of the same thing (coded communication), then perhaps the key to being understood is playing with different genres (opera, novels) and even creating new ones (autobiography). Perhaps only then will he find himself accurately understood by other people.

\section{Books and the Book Industry}

In his youth, Rousseau was a rapacious bibliophile. His mother died during his birth and his father was often away, leaving him ample time to study the many books owned by his father. These were primarily the classics - novels not yet having gained the widespread social acceptance and respectability that they would later in the century. Rousseau's education came primarily through books. Yet, despite the debt that he confesses to owe them, Rousseau would think twice before allowing children to follow in his footsteps and grant them unrestricted access to books. He holds that reading is a plague to childhood (Emile 116) and one can only wonder if this sentiment of his arises out of his own rational observation, or from regretful personal experience. Did he think his life would have turned out differently - that he would have had a different personality and been more socially adept - if he was raised with frequent exposure to company? It may be that he was trying to protect other children from growing up and then living the way he does, awkwardly and embarrassingly, a situation that he may attribute to his being raised by books.

Whether in hindsight he feels that books are good or bad, Rousseau accepted the lending of books to him during his formative years without discrimination and devoured all with equal 
relish. As he confesses, "I read at my workbench, I read on my errands, I read in the privy, where I became lost to the world for hours on end; my brain reeled with reading, I did nothing but read" (Confessions 38). Later in his youth, Rousseau learned restraint and "to read less avidly and more reflectively, and thus to derive more profit from what [he] read" (Confessions 108).

He willingly acknowledges the power of books to change public opinion; not just of himself, but even of an entire people or nation. As a citizen of Geneva (which at the time was an independent city-state) Rousseau was not raised to have a deep love of the French. But, having read extensively the works of French writers, they inspired in him "an affection and, in time, a blind passion" for the French that nothing afterwards had been able to overcome (Confessions 179). For Rousseau, it is the French writers and philosophers who uphold the glory and respectability of France; that same reputation that French warriors, for him, tried so hard to tarnish (ibid).

If he felt that books had this kind of power, it's no wonder that he tried to influence public opinion through the medium, and that he feared books' influence on youth who didn't know enough to analyze them correctly and simply absorb them mindlessly. According to Rousseau, people are immersed in books from their childhood, and accustomed to reading everything without thinking. Thus, what they read "is all the less striking to them since they imagine they already contain within themselves all the information which fills history, and therefore, everyone appears natural to us because we are outside of their nature and judge everyone else by the standards that we set for ourselves" (Emile 241). Prior to literacy, the scrutiny we apply to our friends would not nearly have been so harsh. 
For Rousseau, the power of books was immense and it was a power that was growing, now that books were becoming cheaper and ubiquitous throughout all strata of society. He would try to harness the power of books in his own life, through writing his discourses, his romantic epistolary novel The New Heloise and Emile, his major work on education. Through writing books, Rousseau tried to make a name for himself and gain the reputation of an intelligent, witty and thoughtful man, something that he could never attain through speech. Unfortunately, the power of books proved to be too much for him, even though he was so thoroughly aware of their power.

Rousseau published Emile in 1762, a year after he published Julie to great success. One of the central sections of the work, "The Profession of Faith of a Savoyard Vicar," was meant to be a defense of religious belief. Rousseau advocated the view that, insofar as they lead people to virtue, all religions are equally worthy, and that people should therefore conform to the religion in which they have been brought up. This (personal and sincere) religious indifference caused his books (and Jean-Jacques himself) to be banned from France and Geneva. He was condemned by the Archbishop of Paris, his books were burned, and warrants were issued for his arrest (Damrosch 190). Former friends of Rousseau's could not accept his views, and wrote scathing rebuttals.

Rousseau, who had been trying to defend religion in his writing, was crushed. Forced to flee arrest he made his way to Neuchâtel, a Canton of the Swiss Confederation. Because of this crushing misunderstanding by his friends and the public, Rousseau felt he must defend himself, to reclaim that reputation that was had briefly acquired, notably after winning a renowned prize from the Dijon Academy for his first discourse in 1949. But if he couldn't do it through speech, and he can't do it through books, what then was left to him? 
Rousseau believed that his primary talent was writing. So, after fleeing polite society and his persecutors, he relied once more on his pen, utilizing one medium that was quickly growing in popularity - the open letter - and another that he had to invent from scratch - the autobiography.

\section{Rousseau's Method and Mixed Media in $18^{\text {th }}$ Century Europe}

In his first published work, his Discourse on the Sciences and the Arts, Rousseau's central contention is that that the contributions of all the great writers, thinkers and philosophers throughout the ages have actually added very little to the well-being of men and that, without their contributions, we would be little worse off than presently. If the best of all writers has contributed so little, then what should we think about "that crowd of obscure writers and idle men of letters who to no purpose devour the substance of the state?" (DSA 12). For Rousseau, our modern capacity to write fiction and our leisure to read it leads to a state of luxury, and luxury leads to idleness and mindlessness. This state is even worse than had we been illiterate but physically productive - all along. Rousseau even goes so far as to blame the rise of literacy to the fall of the Roman state; since after acquiring knowledge of letters, they turned away from their warlike (and thriving) existence, to a life of idleness with a central but purposeless appreciation of the arts (DSA 15). According to Rousseau, today,

one no longer asks whether a man has integrity, but whether he has talents; not whether a book is useful, but whether it is well written. Rewards are showered upon the wit, and 
virtue is left without honors. There are a thousand prizes for fine discourses, none for fine actions. (DSA 17)

Previously, before Gutenberg and before literacy, bad writing and even harmful writing would perish with the writer or the age; now however, "thanks to typography and the use we make of it, the dangerous reveries of the likes of Hobbes and Spinoza will remain forever" (DSA 19). This commentary can, in hindsight, be seen as ironic given Rousseau's own reception by society and subsequent censorship across much of Europe (though he, of course, would neither have acknowledged the criticisms or accusations of his detractors, nor comparisons to Hobbes or Spinoza). In a sense, Rousseau had "always short-circuited the normal paths of communication in his culture by setting up an alternative and self-sufficient system for defining self and other, personal identity and cultural role, through the writing and reading of his own work" (Coleman xxviii).

James F. Hamilton suggests that Rousseau liked to distinguish himself from the philosophes (like Diderot and Voltaire) by "putting literature itself on trial. Art [for Rousseau] is evaluated within the framework of civilization" (9). Hamilton calls this a "conspiratorial theory of art," whereby the influencers of society are those wealthy few people who set the agenda for the remainder to follow; to modern readers and theorisis this may seem like contemporary Marxist theory. Rousseau accuses the man of letters not only of selfishness and poor citizenship but, more significantly, of "active collaboration in the subordination and enslavement of the public" (Hamilton 12). Art fundamentally "blinds man to the fact of his eroding freedom by preoccupying his mind with an illusory, aesthetic realm of values and events" (Hamilton 12). 
Thus, Rousseau foresees a possible time when printing presses and literature will yet be denounced and destroyed, as humankind yearns to cast off its chains and return to a pre-literate innocence (apparently we have to pass through a digital age before this can occur, if Rousseau is right). He suggests that the reasons behind burning the library at Alexandria, while now disdained as absurd, would hold just as well in modern times if the Koran were replaced with the Gospels: that which is contrary to the Bible is bad and should be burned, while that which is in conformity with the Bible is superfluous and should be burned anyway (DSA 19, footnote). Rousseau felt that if, when a sufficiently informed populace deliberates, the citizens were to have no communication among themselves, the general will would always result from the large number of small differences, and the deliberation would always be good. But when intrigues and partial associations come into being at the expense of the large association, the will of each of these associations becomes general in relation to its members and particular in relation to the state. (DSA 156)

The possibility of intrigue and discord rises with the number of pamphlets and tasteless newspapers that are available; though this isn't to say that Rousseau himself is above using this system of the public's captivation with trashy media to his advantage.

Regarding intrigues, a newer medium was on the rise and gaining popularity in society. Although all forms of printing were increasing rapidly, and the novel was a new medium growing in popularity and respect, Rousseau was among a number of writers who were experimenting with shaping public opinion by publishing open letters; indeed, Jürgen Habermas 
characterises the eighteenth century as "the century of the letter" (48).. The newly widespread availability of the presses allowed the cheap production of brochures and pamphlets, and allowed Rousseau to capitalize on the demand for public scandal and intrigue. His Letter to D'Alembert on Spectacles, both an essay and a letter (written response to an article published in the Encyclopédie by Jean d'Alembert), proposed the establishment of a theatre in Geneva. The Letter is highly personally relevant to Rousseau, whose patriotism for Geneva shows through, as he writes to defend his country from moral decay. By focusing on his belief in the natural order and harmony of traditional sex roles and community, Rousseau writes to convince d'Alembert, and the public of Geneva, that a theatre is a threat to an ideal and natural way of life (Damrosch 145). It was republished numerous times and had great impact on public discourse at the time, particularly relating the issue of a theatre in Geneva to the broader social context, warning of the potential of theatre to corrupt the morality of society.

Rousseau used open letters like this, which captured the public demand for intrigue, in combination with his other writing, to sway public opinion. Again, however, his lifelong plague of being misunderstood would find its way even into his open letters, forcing him to turn to another medium altogether - one that he would have to invent.

Throughout his body of work, Rousseau constantly pleads to be judged and evaluated. However, as soon as he suspects he's been judged (and even if that judgment is favourable), he feels misjudged, "mistaken for someone else, distorted, tried in absentia with no chance to defend himself" (Starobinski 143). He thought that one way around this would be to create a new genre of writing, one that would show him as he is without artifice or flattery or modesty: the autobiography. Feeling that he needed to clear his name and reputation, and believing himself to be a good man with pure motives, Rousseau began work on a series of documents, 
autobiographical in nature, that he hoped would allow the public to see him as he truly was. These included The Reveries of the Solitary Walker (1782) and his Dialogues (1782), though the most substantial of these personal works was his Confessions (1782). This work Rousseau claimed would be the complete truth of his life, encapsulating all of his faults and untainted by embellishments or any care for projecting an untrue, unrealistically attractive version of him. According to Rousseau, this would be the first time such an endeavour was ever undertaken and would be an invaluable resource to humanity.

However, his project again didn't turn out quite as he had hoped. For Mark J. Temmer, sympathetic readers of the Confessions should be wary of Rousseau's sincerity, which "casts an imperceptible spell as they turn the pages of his book. The progressive crystallization of the artistic vision ... cannot be understood by the study of disconnected chapters and episodes. On the contrary, the captivation of the reader depends upon his willingness to accept the temporal perspective of the author, and, because of the stylistic importance of his suggestions of an illusory past, present and future" (2). A reader might assume that Rousseau took care not to present a false portrayal of past incidents and feelings, but this assumption would be false. On the contrary, to relate one's life is to simulate the characteristics of time as they are experienced, "whether they are the uncertainty of things to come, the solidity of the present, or the redoubtable quiescence of what is past" (Temmer 3). Rousseau was guilty of embellishment and falsity in his Confessions, a work about his own life and one which he repeatedly assured his readers was absolutely true.

Because it was a new genre to modern literature (and scholars agree that Rousseau's Confessions did indeed help lay the groundwork for what became the present day autobiography) Rousseau felt that he was forced to play with styles in the work and not be restricted to a single 
mode of storytelling. In the preface to the Neuchâtel edition (1764) of his Confessions, he states that in writing about his life he must constantly make decisions as to style as well as substance:

I will not attempt to make this style uniform: I will always adopt whichever one presents itself ... will change it according to my mood and without scruple... and my style, uneven and natural, now rapid and now diffuse, now sober and now extravagant, now grave and now gay, will itself be part of my story. (Confessions 648 )

Rousseau's Confessions were to be a book precious to philosophers, since it was purported to offer a "point of comparison for the study of the human heart, and it is the only such document in existence" (648). He defined them as "the only portrait of a man, painted exactly according to nature and in all its truth, that exists and will probably ever exist" (Confessions 3 ). Another lens which we can use to view Rousseau's theories on open letters and related media is through that of the $18^{\text {th }}$ Century development of the public sphere, as put forward by Jürgen Habermas. He suggests that the increase in the traffic of news corresponded (from the $14^{\text {th }}$ to the $18^{\text {th }}$ century) with the increase in the traffic of commodities, and that this directly resulted in the development of news and literature on demand (16), and news as commodity (21). Habermas further points out that the burgeoning public sphere was the primary authority, and that "there was scarcely a great writer in the eighteenth century who would not have first submitted his essential ideas for discussion [to it and] ... a new work, even a musical one, had to legitimate itself first in this forum" (34). Thus, the public became the authority on philosophical thought and the arts, and discussion became the medium through which people legitimized these two disciplines; for a time periodicals and pamphlets became authorities on truth. Rousseau was 
thus well-placed to use these new media to establish his reputation, then defend his reputation, then denounce his detractors and, finally, secure for himself a place above most public criticism.

Admission to the recognized authoritative public of Rousseau's time was based largely on literacy; however, if education was an important criterion of membership, then property ownership remained primary. Habermas suggests that the gradual switch in perception from the wellbeing of private individuals (i.e. landowners) to a concern for the public good is what allowed Rousseau to postulate his theory of the general will and to have it so universally acclaimed by his critics (93). His uneasy approval by the public may have had a similar source.

Looking beyond his influence on public opinion on philosophers, one of the most central effects of Rousseau's work was to upset the societal conventions about what constituted relevant detail in the general reader's response to a specific author. What did Rousseau need to know about them to understand where they stood in relation to society as they were now - thanks to him - beginning to see it? After the "catastrophic misunderstanding of his intentions signalled by the banning of his books, Rousseau turns this question around and makes it the basis for his autobiography. What does he need to tell his readers to make them understand him? ... the answer [for Rousseau] is 'everything"' (Coleman xxiii).

Rousseau felt that, al though he would not intentionally embellish any of his faults, the underlying goodness of his character would reveal the goodness of his actions and that his motives, when once seen truthfully, would compel even his greatest enemies to understand him. Of course, substantial scholarly work has shown that his Confessions were, as mentioned, extensively embellished. Although his open letters and autobiography did not achieve for Rousseau salvation of his reputation during his lifetime, they did secure for him a legacy after his 
death. As well, they provided scholars a unique look into his psyche, and gave us a new medium with which the human race can define itself.

\section{Conclusion}

Throughout his work, Rousseau shows a concern for problems of communication. Be it in his advice on education, his enquiries into the origin of languages, or his motivation for writing open letters and works of autobiography, threads of coherence run through his work. He was preoccupied with being misunderstood in writing the way he felt he was in person. He would write philosophical discourses to get his major political points across, yet buttress these with works of fiction like The New Heloise, open letters to prominent members of society, and correspondence that he would circulate among his acquaintances and allow to be copied and distributed. He wanted always to get his meanings clear, yet he was constantly re-defining words. His longest work, his Confessions - while professing repeatedly to be an absolutely true and unbiased account of his life as only he could tell it - is easily shown by historians (and disclaimed by Rousseau's contemporary critics) to have been exaggerated and misleading in many respects.

Rousseau was a man of contradictions. He was:

the subordinate who criticizes the false values of society while desperately seeking distinction, the writer of plays who condemns the theatre, the father who abandons his children and composes a monumental work on pedagogy, the man who idealizes women 
but restricts their intellectual development ... the personality of Rousseau proves to be both a help and a hindrance to the literary critic. (Hamilton xii)

His largest communications-related concern is with the origins of language, and he pursues this in order to understand how language has arrived in its present state: in some unsatisfactory middle-development between simple grunts and gestures, and a perfect system of communication that would allow all men to understand each other and to be understood flawlessly. Rousseau's motivation in this case seems to be that if we can ascertain how language got its start, perhaps we can help it move forward to achieve the kind of perfect and immediate communication that should already have been in our grasp centuries ago. Then, perhaps, people would cease misunderstanding one another.

In writing his Confessions, Rousseau was well aware of the fallibility of memory and the difficulties of clear communication; the different perceptions that two people will have of the same event. He declares, therefore, that he will relate events as precisely as possible in the hope that his readers will derive their own conclusions. It is not for Rousseau to "judge the importance of the facts, [he] must simply relate them all and leave to [his reader] the task of choosing among them" (Confessions 170). By looking solely at the many themes of communication in his work we can see that Rousseau, writing in the mid- $18^{\text {th }}$ Century, was a significant thinker of and contributor to modern communication thought. 


\section{Appendix}

\section{Quantitative Content Analysis of Communication Thought in $17^{\text {th }}$ and $18^{\text {th }}$ Century French Writers}

\section{Introduction}

This analysis considers the question: Was communication theory a more widely discussed topic among major French writers in the $18^{\text {th }}$ Century than in the $17^{\text {th }}$ Century? If successful, this quantitative analysis would show that the origins of foundational modern communication thought were in the $18^{\text {th }}$ century, as evidenced by the work of Diderot, Rousseau and Voltaire. Unfortunately however, the results indicate that while topics such as communication, language and physical media were, on the whole, discussed more often among French thinkers of the later century, the difference in frequency is not statistically significant.

\section{Method and sample}

This research considers the work of six central French writers of the $17^{\text {th }}$ and $18^{\text {th }}$ Century. From the $17^{\text {th }}$ Century I have selected the philosophers Rene Descartes (1596-1650) and Blaise Pascal (1623-1662) and the satirical writer Molière (1622-1673). From the $18^{\text {th }}$ Century, I have selected the philosophers Jean-Jacques Rousseau (1712-1778) and Voltaire (1694-1778) and, to balance Molière, the fiction/satire writer Denis Diderot (1713-1784). 
Using a frequency analysis of key words in the three main works of each of these these writers, this investigation aims to discover if the foundations of mass communication had a significant beginning in the $18^{\text {th }}$ Century on the European continent as opposed to the previous century. Underlying this investigation, I propose that the 1700 s were an exciting and transformative time for mass communications in the Western world. Newspapers were finally coming into their own and novels were arising as a distinct genre. Political commentary disseminated through bulletins or one-sheet newspapers was vibrant and the growing use of moveable-type printing presses enabled, for the first time in history, cheap, quick and wide distribution of printed information. While much modern writing has considered the introduction of these innovations to political and social life, few analysts take a close look at what was being written about mass printed communications, by the most notable thinkers, during this period.

In order to determine whether the $18^{\text {th }}$ Century was, indeed, a time of considerable transformation in the public discourse of communications and media theory, this analysis looks at the most popular works of these six writers over two centuries. I am working on the assumption that, given that these works were by the most famous and widely-read writers of their period, most likely their work both reflected and influenced public discourse of the time. Thus, from these six writers, 1 selected the three major works from each, for a total of eighteen works, totaling over 800,000 words. The consideration behind this decision is that the writers' major works would have been most widely read among the French-speaking public at the time and, thus, their content would have had the most impact on French discourse. The works under consideration are as follows: 
$17^{\text {th }}$ Century:

Descartes: Discourse on the Method; Principles of Philosophy; The World

Molière: the Bourgeois Gentleman; the Hypocrite; Psyche

Pascal: The Art of Persuasion; Pensèes; The Provincial Letters

$18^{\text {th }}$ Century:

Diderot: First Satire; Jacques the Fatalist and His Master; Rameau's Nephew

Rousseau: Discourse on Inequality; Emile; On the Social Contract

Voltaire: Candide; The Ingenu; Zadig

\section{Counting and Coding}

In order to determine the quantity of discussion of communication, language or media-related issues, I performed a simple frequency count of the number of times certain key words appeared in the major works of these six authors. I considered the word "communication" and its derivatives (communicates, communicated) ignoring those instances when it occurred as part of an unrelated word (as, for example, the word excommunicated, a very common topic among French thinkers in both the $17^{\text {th }}$ and $18^{\text {th }}$ Centuries). I also performed the same counting exercise for the word "language". I felt it was also important to see how often physical media themselves were discussed, and so looked at the three primary means of communication at the time, searching for the terms "newspaper," "book," and "pamphlet."

Since - even in the works of the most explicit modern communication theorists - these key words will always appear as a tiny fraction of the whole, I then analyzed how often these words appeared in each writer's work per thousand words. I analyzed these distributions based 
on number of times the key words appeared in the writings of the philosophers (those excluding Molière and Diderot) and then as part of the six French writers' works as a whole. When coding the results, I utilized Fisher's test for a $2 \times 2$ contingency table. I considered the two groups of work of the two French philosophers from each century (Descartes \& Pascal versus Rousseau \& Voltaire) and then combined that group with the satirists from their respective centuries (Molière and Diderot).

\section{Analysis}

As the $P$ value equals 0.542 , the association between the groups and the outcomes is considered to be not statistically significant, i.e. $18^{\text {th }}$ Century French thinkers were not writing about media and communication theory to a statistically higher degree than they had been in the previous century.

\section{Conclusions}

While the analysis was not statistically significant, the exercise as a whole was, I believe, valuable. It did show that discussion of communication, language and media-related themes was on the rise among prominent writers. Future research might consider a wider array of writers, or a greater number of works from each writer (or both). It might also compare $17^{\text {th }}$ Century writers to $18^{\text {th }}$ and $19^{\text {th }}$ Century writers to see if there is an overall trend in the discourse. 


\begin{tabular}{|c|c|c|c|c|c|c|}
\hline & $\begin{array}{c}\text { Communicate/ } \\
\text { Communication }\end{array}$ & Language & $\begin{array}{c}\text { Media } \\
\text { (Newspaper, } \\
\text { Book or } \\
\text { Pamphlet) }\end{array}$ & $\begin{array}{c}\text { \#of Key } \\
\text { Terms in } \\
\text { Works }\end{array}$ & $\begin{array}{c}\text { Total } \\
\text { Words } \\
\text { in } \\
\text { Works }\end{array}$ & $\begin{array}{c}\text { Appearances } \\
\text { per } \\
\text { thousand } \\
\text { words }\end{array}$ \\
\hline $\begin{array}{c}\text { Rene } \\
\text { Descartes }\end{array}$ & 17 & 9 & 15 & 41 & 87,400 & 0.47 \\
\hline $\begin{array}{c}\text { Molière } \\
\text { Blaise } \\
\text { Pascal }\end{array}$ & 0 & 7 & 1 & 8 & 62,000 & 0.13 \\
\hline $\begin{array}{c}\text { Denis } \\
\text { Diderot }\end{array}$ & 14 & 32 & 34 & 80 & 226,700 & 0.35 \\
\hline $\begin{array}{c}\text { Jean- } \\
\text { Jacques } \\
\text { Rousseau }\end{array}$ & 18 & 95 & 128 & 241 & 202,300 & 1.19 \\
\hline \begin{tabular}{c} 
Voltaire \\
\hline
\end{tabular} & 6 & 18 & 39 & 63 & 102,900 & 0.61 \\
\hline
\end{tabular}

\section{$17^{\text {th }}$ Century:}

Descartes: Discourse on the Method 26,000 (7, 6, [0, 8, 0]); Principles of Philosophy 33,700 $(3,0$, $[0,7,0]) ;$ The World $27,700(7,3,[0,0,0])$

Molière: The Bourgeois Gentleman 21,400 $(0,6,[0,0,0]) ;$ The Hypocrite $21,100(0,0,[0,1,0])$; Psyche $19,500(0,1,[0,0,0])$

Pascal: The Art of Persuasion 4,400 $(0,0,[0,3,0])$; Pensèes $114,900(3,6,[0,10,0])$; The Provincial Letters $107,400(11,26,[0,18,3])$

\section{$18^{\text {th }}$ Century:}

Diderot: First Satire 3,500 (0, 0, [0, 0, 0]); jacques the Fatalist and His Master 99,200 (4, 32, [2, $48,2]) ;$ Rameau's Nephew $33,200(0,8,[0,12,0])$

Rousseau: Discourse on Inequality 35,600 (8, 28, [0, 3, 0]; Emile 163,800 (4, 38, $[1,117,3])$; On the Social Contract $29,000(6,29,[0,4,0])$

Voltaire: Candide $39,000(3,8,[0,14,2])$; The Ingenu $29,600(0,7,[0,10,1])$; Zadig $34,300(3,3$, $[0,12,0])$ 
Table 2

\begin{tabular}{|c|c|c|c|c|c|c|c|}
\hline & $\begin{array}{c}17^{\text {th }} \\
\text { Century } \\
\text { Phil's }\end{array}$ & $\begin{array}{l}18^{\text {th }} \\
\text { Century } \\
\text { Phil's }\end{array}$ & $\Delta$ Phil's & $\begin{array}{c}17^{\text {th }} \\
\text { Century- } \\
\text { All Writers }\end{array}$ & $\begin{array}{c}18^{\text {th }} \\
\text { Century - } \\
\text { All Writers }\end{array}$ & $\Delta W$ riters & P value $^{1}$ \\
\hline $\begin{array}{l}\text { Key Terms } \\
\text { per } \\
\text { Thousand } \\
\text { Words }\end{array}$ & 0.385 & 0.996 & 0.611 & 0.343 & 0.934 & 0.591 & 0.542 \\
\hline
\end{tabular}

1 - $P$ value was derived using Fisher's exact test for a $2 \times 2$ contingency table, with one group comprised of $17^{\text {th }}$ Century Philosophers (excluding Molière) and $17^{\text {th }}$ Century Writers as a whole versus a second group comprised of $18^{\text {th }}$ Century Philosophers (excluding Diderot) and $18^{\text {th }}$ Century Writers as a whole. For the purposes of analysis, the number of key terms per thousand words was multiplied by 1000 , to make the values integers. As the $P$ value equals 0.542 , the association between the groups and the outcomes is considered to be not statistically significant, i.e. $18^{\text {th }}$ Century French thinkers were not writing about media and communication theory to a statistically higher degree than they had been in the previous century. 


\section{Works Cited}

Bloom, Allan. "Introduction" in Emile, or, On Education, by Jean-Jacques Rousseau. United States: Basic Books. 1979.

Butterworth, Charles E. "Interpretive Essay" in The Reveries of the Solitary Walker. Indianapolis: Hackett Publishing Company, 1992.

Coleman, Patrick. "Introduction" in Confessions, by Jean-Jacques Rousseau. Oxford: Oxford University Press. 2008.

Damrosch, Leo. Jean-Jacques Rousseau: Restless Genius, New York: Houghton Mifflin. 2005.

Gay, Peter. "Introduction" in Jean-Jacques Rousseau: The Basic Political Writings. Indianapolis: Hackett Publishing Company. 1987.

Habermas, Jürgen. The Structural Transformation of the Public Sphere: An Inquiry into a Category of Bourgeois Society. Cambridge, MA: The MIT Press. 1991.

Hamilton, James F. Rousseau's Theory of Literature: the Poetics of Nature. York, South Carolina: French Literature Publications Company. 1979.

Kavanagh, Thomas M. Writing the Truth: Authority and Desire in Rousseau. Berkeley: University of California Press. 1987.

Rousseau, Jean-Jacques. Confessions. Trans. Angela Scholar. Oxford: Oxford University Press. 2008. 
Rousseau, Jean-Jacques. "Discourse on the Origin of Inequality", in Jean-Jacques Rousseau: The Basic Political Writings. Trans. Donald A. Cress. Indianapolis: Hackett Publishing Company. 1987.

Rousseau, Jean-Jacques. "Discourse on Political Economy", in Jean-Jacques Rousseau: The Basic Political Writings. Trans. Donald A. Cress. Indianapolis: Hackett Publishing Company. 1987.

Rousseau, Jean-Jacques. "Discourse on the Sciences and the Arts", in Jean-Jacques Rousseau: The Basic Political Writings. Trans. Donald A. Cress. Indianapolis: Hackett Publishing Company. 1987.

Rousseau, Jean-Jacques. Emile, or, On Education. Trans. Allan Bloom. United States: Basic Books. 1979

Rousseau, Jean-J acques. "Essay on the Origin of Languages" in The First and Second Discourses: together with the replies to critics and Essay on the Origin of Languages. Trans. Victor Gourevitch. New York: Harper and Row. 1990.

Rousseau, Jean-Jacques. "Letter to D'Alembert" in Politics and Art: Letter to D'Alembert on the Theatre. Trans. Allan Bloom. Ithaca NY: Cornell University Press. 1968.

Rousseau, Jean-Jacques. "On the Social Contract", in Jean-Jacques Rousseau: The Basic Political Writings. Trans. Donald A. Cress. Indianapolis: Hackett Publishing Company. 1987. 
Rousseau, Jean-Jacques. La Nouvelle Heloise (Julie, or The New Eloise): Letters of two lovers, inhabitants of a small town a the foot of the Alps. University Park, Pennsylvania: The Pennsylvania State University Press. 1968.

Rousseau, Jean-Jacques. The Reveries of the Solitary Walker. Trans. Charles E. Butterworth. Indianapolis: Hackett Publishing Company. 1992.

Starobinski, Jean. Jean-Jacques Rousseau: Transparency and Obstruction. Trans. Arthur Goldhammer. Chicago: University of Chicago Press. 1971.

Temmer, Mark J. Art and Influence of Jean-Jacques Rousseau: The pastoral, Goethe, Gottfried Keller, and other essays. Chapel Hill: The University of North Carolina Press. 1973.

Wurman, Richard Saul. Information Anxiety. Indianapolis, IN: Que, 2001. 